Zeszyty Naukowe Szkoły Głównej Gospodarstwa Wiejskiego

Ekonomika i Organizacja Gospodarki Żywnościowej nr 120, 2017: 147-157

DOI 10.22630/EIOGZ.2017.120.45

Ewa Świstak, Monika Świątkowska

Wydział Nauk o Żywieniu Człowieka i Konsumpcji

Szkoła Główna Gospodarstwa Wiejskiego w Warszawie

\title{
Oferta gastronomiczna hoteli warszawskich w ocenie ich gości
}

\section{Wstęp}

Podnoszenie się standardu życia ludzi, wzrost znaczenia usług turystycznych i zwiększenie wydatków na żywienie poza domem w gospodarstwach domowych to czynniki sprzyjające rozwojowi sektora gastronomicznego. Obok placówek wyspecjalizowanych w świadczeniu takich usług na rynku funkcjonują różne ich formy ulokowane na terenie obiektów hotelarskich, które pełnią kluczową funkcję w zaspokajaniu jednej z głównych potrzeb osób przebywających poza miejscem stałego zamieszkania - potrzeby wyżywienia. Oprócz tego oferta tych zakładów w dużym stopniu stanowi element wyróżniający na rynku, budujący wizerunek i przyciągający klientów.

\section{Rola i zakres usług gastronomicznych w obiektach hotelarskich}

Usługi gastronomiczne, obok noclegowych, stanowią najważniejszą część produktu oferowanego przez hotele. Zgodnie z klasyfikacją według kryterium zakresu świadczenia zaliczane są one do usług podstawowych, wspólnych dla wszystkich rodzajów obiektów hotelarskich [Świątkowska 2009, Drogoń i Granecka-Wrzosek 2013].

Do funkcji usług gastronomicznych należy przede wszystkim zapewnienie posiłku gościowi obiektu, ale także spełnienie jego oczekiwań w zakresie potrzeb wyższego rzędu, takich jak: chęć poznania nowych smaków lub powrotu do dań tradycyjnych, skosztowania potraw wykwintnych, oryginalnie zaprezen- 


\section{8}

towanych, relaksu w eleganckim wnętrzu w atmosferze gościnności czy skorzystania z działalności rozrywkowej lokali [Mańkowski 2008].

Zadania gastronomii hotelowej polegają na serwowaniu śniadań i innych posiłków nie tylko gościom hotelowym, ale także klientom zewnętrznym oraz na obsłudze imprez biznesowych, okolicznościowych i świadczeniu usług cateringowych [Mitura i Koniuszewska 2008, Cieślik i in. 2011].

Działalność gastronomiczna obejmuje zakup i przetwarzanie surowców w gotowe do podania potrawy. Im wyższa kategoria hotelu, tym bardziej rozwiniętej gastronomii i atrakcyjnego programu usług oczekuje gość hotelowy [Mucha-Szajek 2001a]. W Polsce spełnienie tych oczekiwań w pierwszym rzędzie regulują wymogi kategoryzacyjne, zgodnie z którymi [Rozporządzenie 2011]:

- każdy hotel jest zobowiązany do zapewnienia gościom gorącego napoju i śniadania; są to jedyne wymogi w zakresie usług żywieniowych, dotyczące obiektów jednogwiazdkowych;

- na terenie hotelu przynajmniej dwugwiazdkowego powinien znajdować się bar;

- obiekty kategorii trzygwiazdkowej i wyższej powinny świadczyć usługę room service przynajmniej przez 18 godzin na dobę, a także udostępniać gościom restaurację, przy czym dla hoteli trzygwiazdkowych jest to wymóg warunkowy i nie musi być spełniony, jeśli w pobliżu obiektu znajduje się restauracja w odległości nie większej niż $500 \mathrm{~m}$.

Wymogi kategoryzacyjne wyznaczają minimalny zakres usług gastronomicznych. Wielkość zespołu gastronomicznego w hotelu warunkowana jest ponadto wielkością obiektu, jego lokalizacją, rodzajem obsługiwanego segmentu rynku. W hotelach o wysokim standardzie dział ten najczęściej obejmuje: restauracje, lobby bary, kawiarnie, puby, lokale nocne, bary aperitif i inne. Wszystkie lokale wzajemnie uzupełniają się, tworząc kompleksową ofertę żywieniową [Sala 2011].

Zdaniem Mańkowskiego [2008] specyfika usług gastronomicznych polega na kontakcie i właściwych relacjach personelu z klientem. Współczesny rynek usług gastronomicznych cechuje duża konkurencja, co powoduje, że przedsiębiorstwa hotelarskie i gastronomiczne dążą do podwyższenia jakości w sferze obsługi konsumenta. Na jakość obsługi zasadniczy wpływ mają wysokie kwalifikacje pracowników, zwłaszcza personelu pierwszego kontaktu (obsługa kelnerska, barmani, kierownik sali), właściwa organizacja pracy, sposób serwowania dań, oferowane menu, wystrój lokalu, a także cena. Autor podkreśla, iż sprawna organizacja i jakość obsługi uwarunkowana jest prawidłową współpracą zespołu kelnerskiego oraz kuchni.

Według Nadulskiego [2011] usługi gastronomiczne odznaczają się cechami, takimi jak: 
- niematerialność i nietrwałość usługi,

- jedność procesów tworzenia i konsumowania usługi,

- współgranie wielu elementów, które decydują o efekcie końcowym usługi,

- uzupełnianie się usług gastronomicznych i noclegowych,

- brak możliwości magazynowania usług,

- sezonowy charakter usług,

- lokalny zasięg działalności gastronomicznej, często ograniczony do wąskiej grupy konsumentów (gości hotelowych, grup turystycznych),

- aktywny udział konsumenta w procesie świadczenia usługi,

- kwalifikacje personelu jako czynnik decydujący w istotnym zakresie o zadowoleniu klienta.

Gastronomia jest jednym ze znaczących źródeł dochodu w hotelarstwie [Mucha-Szajek 2001b]. Z tego względu ma szczególne znaczenie w okresach mniejszego wykorzystania miejsc noclegowych (np. w weekendy), kiedy hotel może czerpać zyski z wizyt w swoich lokalach miejscowej ludności i obsługi zamawianych imprez okolicznościowych. Spodziewane przychody z własnej gastronomii wymagają uwzględnienia przez przedsiębiorstwo hotelarskie sezonowego charakteru świadczonych usług oraz różnorodnych oczekiwań klientów decydujących o końcowym efekcie usługi poprzez jej ocenę [Knowles 2001]. Odpowiedni standard usług gastronomicznych ma istotny wpływ na postrzeganie całej usługi hotelarskiej oraz stopień usatysfakcjonowania gości, przyczyniając się do tworzenia wizerunku hotelu. Ponadto na działalność gastronomii hotelowej decydujący wpływ mają także jej cechy, dzięki którym może ona spełniać określone cele.

Według Graneckiej-Wrzosek [2013] gastronomia hotelowa ma następujące cele:

- satysfakcję klientów przez tworzenie nowych ofert,

- wzrost obrotów działu gastronomicznego w hotelu oraz generowanie wysokiej stopy zysku,

- optymalizację wydajności produkcji,

- uwzględnienie środowiska naturalnego przez jego ochronę.

Do głównych cech gastronomii hotelowej należy zaliczyć [Granecka-Wrzosek 2013]:

- różnorodność zakładów gastronomicznych,

- wysoki poziom obsługi,

- atrakcyjną ofertę potraw,

- całodobową gotowość obsługową (w obiektach o wysokim standardzie),

- odpowiedni klimat restauracji hotelowej,

- niekonwencjonalny wystrój,

- ciekawy program artystyczny. 
Kluczowym elementem wpływającym na sukces w gastronomii hotelowej jest wysoki standard obsługi. Należy jednak pamiętać, że z usług gastronomii hotelowej korzystają goście o różnych preferencjach, którzy postrzegają obsługujący ich personel z perspektywy indywidualnego przekonania i własnego doświadczenia. Często od zachowania pracowników zależy ocena usług danego przedsiębiorstwa. Dla przedsiębiorstw hotelarsko-gastronomicznych ważne jest, aby klienci opuszczali je zadowoleni, ponieważ satysfakcja z usług wpływa na ich zaufanie i lojalność. Jeśli gość nie jest usatysfakcjonowany, skorzysta z innej oferty, bardziej spełniającej jego oczekiwania [Cieślik i in. 2014]. Badania Nadulskiego [2011] wskazuja, że wysoka kultura osobista została uznana za najważniejszą cechę pracownika gastronomii hotelowej, podobnie jak uprzejmość oraz sprawność obsługi.

\section{Cel, zakres i metodyka pracy}

Celem pracy była ocena usług gastronomicznych świadczonych w hotelach warszawskich dokonana przez ich gości. Ocenie poddano szeroko rozumianą ofertę lokali gastronomicznych, a także czynniki związane z obsługą konsumentów. Źródło informacji stanowiły wyniki dwóch badań pierwotnych, przeprowadzonych metodą ankietową.

W pierwszym, zrealizowanym w 2013 roku, kwestionariusz ankiety rozprowadzono wśród gości sześciu warszawskich hoteli wybranych metodą celowo-losową, różniących się standardem (po dwa hotele cztero-, trzy- i dwugwiazdkowe). W badaniu uczestniczyło łącznie 120 respondentów (po 40 respondentów przypadających na każdą kategorię hoteli). Kwestionariusz ankiety składał się z 14 pytań zamkniętych. Do analizy dokonanej w ramach niniejszej pracy wybrano pytania dotyczące oceny usługi gastronomicznej pod kątem jakości obsługi gości oraz jakości oferowanych potraw. W ocenie menu lokali gastronomicznych w badanych hotelach wzięto pod uwagę $10 \mathrm{cech}$. Zastosowano pięciostopniową skalą punktową gdzie 1 punkt oznacza ocenę najniższą, a 5 punktów ocenę najwyższą.

W drugim badaniu, zrealizowanym w 2016 roku, wykorzystano kwestionariusz ankiety w formie internetowej, który składał się z 19 pytań merytorycznych. Kwestionariusz zawierał pytania dotyczące oceny usługi gastronomicznej hoteli warszawskich w kontekście jakości obsługi konsumenta, oferowanych usług gastronomicznych oraz usług dodatkowych. W ocenie oferty menu hotelowych lokali gastronomicznych wzięto pod uwagę $14 \mathrm{cech}$. W badaniu uczestniczyło 150 respondentów korzystających z usług gastronomicznych hoteli zlokalizowanych na terenie Warszawy. Zastosowana pięciopunktowa skala posłuży- 
ła do określenia wpływu danej cechy usługi gastronomicznej na postrzeganie jej jakości przez klienta. W tym przypadku 1 punkt oznacza wpływ nieistotny, 5 - wpływ bardzo istotny.

Do interpretacji wyników posłużono się ocenami średnimi.

\section{Charakterystyka i ocena oferty gastronomicznej w zależności od standardu hotelu}

W 2013 roku elementy związane z ofertą dań i sposobem ich podania były na ogół wyżej oceniane w badanych hotelach czterogwiazdkowych. Wyjątki od tej zasady stanowiła ocena wyglądu potraw - znacznie niższa w hotelach trzygwiazdkowych niż w cztero- i dwugwiazdkowych oraz ocena wielkości porcji - najwyższa w hotelach trzygwiazdkowych. W hotelach czterogwiazdkowych najlepiej, na poziomie blisko 5 punktów, oceniono ofertę napojów, nieznacznie niżej nakrycie stołu i uwzględnianie indywidualnych życzeń gości, najniżej zaś sklasyfikowano wielkość porcji i temperaturę potraw. Ocenę poniżej 4 punktów uzyskały takie elementy usługi, jak: smak potraw, czytelność karty menu oraz czas oczekiwania na posiłek. W hotelach trzygwiazdkowych oprócz wielkości porcji, wyróżniono także ofertę napojów i nakrycie stołu, najbardziej krytycznie oceniono zaś wygląd i smak potraw oraz uwzględnianie indywidualnych życzeń. Goście hoteli dwugwiazdkowych najwyżej ocenili wygląd i smak potraw, najniżej czytelność karty menu i urozmaicenie oferty (tab. 1).

Tabela 1

Ocena oferty menu lokali gastronomicznych w zależności od standardu hotelu w 2013 roku

\begin{tabular}{|l|c|c|c|}
\hline \multirow{2}{*}{ Oceniane elementy usługi } & \multicolumn{3}{|c|}{ Średnie oceny dla hoteli } \\
\cline { 2 - 4 } & $\begin{array}{c}\text { dwu- } \\
\text { gwiazdkowych }\end{array}$ & $\begin{array}{c}\text { trzy- } \\
\text { gwiazdkowych }\end{array}$ & $\begin{array}{c}\text { cztero- } \\
\text { gwiazdkowych }\end{array}$ \\
\hline Urozmaicenie oferty potraw & 2,78 & 3,60 & 4,10 \\
\hline Oferta napojów & 3,20 & 3,98 & 4,90 \\
\hline Temperatura potraw & 3,21 & 3,55 & 3,78 \\
\hline Wielkość porcji & 3,35 & 4,15 & 3,65 \\
\hline Smak potraw & 3,63 & 3,68 & 3,90 \\
\hline Wygląd potraw & 3,68 & 3,05 & 4,15 \\
\hline Uwzględnianie indywidualnych życzeń & 2,85 & 3,38 & 4,38 \\
\hline Wygląd i czytelność karty menu & 2,75 & 3,65 & 3,90 \\
\hline Nakrycie stołu & 3,15 & 3,80 & 4,63 \\
\hline Czas oczekiwania na posiłek & 3,00 & 3,63 & 3,80 \\
\hline
\end{tabular}

Źródło: Badanie własne. 
W badaniu przeprowadzonym w 2016 roku spośród czynników odnoszących się do menu respondenci najwyżej ocenili walory smakowe potraw oraz przystępną cenę. Tuż za nimi uplasowały się takie elementy usługi, jak: szeroki i urozmaicony asortyment potraw uwzględniający różnorodne preferencje klientów, walory wizualne potraw, duża wartość odżywcza serwowanych potraw oraz walory zapachowe potraw. Nieco niżej oceniono wprowadzanie produktów sezonowych do menu oraz oryginalność oferty. Zróżnicowanie i dostosowanie karty menu do pór dnia oraz dostosowanie oferty żywieniowej do indywidualnych potrzeb także znalazły się wśród czynników w dużym stopniu wpływających na ocenę usługi. Specjalności dań narodowych i regionalnych również decydowały o ocenie lokalu gastronomicznego. Mniej ważne dla osób korzystających z oferty gastronomicznej hoteli były gotowe zestawy oferowane w menu. Badani najniżej ocenili atrakcyjność kart menu i ulotek oraz specjalne oferty okolicznościowe.

Analiza zależności między wpływem oferty menu na ocenę lokalu gastronomicznego a kategorią hotelu wykazała, że dla klientów obiektów dwu-, trzyi czterogwiazdkowych przystępne ceny były równie ważnym czynnikiem wpływającym na ogólną ocenę lokalu, choć należy zauważyć, że ich klienci zwracali większą uwagę na walory smakowe potraw. Dodatkowo w hotelach czterogwiazdkowych elementem oferty menu mającym duży wpływ na ocenę lokalu był szeroki i urozmaicony asortyment potraw uwzględniający różnorodne preferencje klientów (4,92 punktów) - tabela 2.

Tabela 2

Ocena oferty menu lokali gastronomicznych w zależności od standardu hotelu w 2016 roku

\begin{tabular}{|c|c|c|c|}
\hline \multirow[b]{2}{*}{ Oceniane elementy usługi } & \multicolumn{3}{|c|}{ Średnie oceny dla hoteli } \\
\hline & $\begin{array}{c}\text { dwu- } \\
\text { gwiazdkowych }\end{array}$ & $\begin{array}{l}\text { trzy- } \\
\text { gwiazdkowych }\end{array}$ & $\begin{array}{c}\text { cztero- } \\
\text { gwiazdkowych }\end{array}$ \\
\hline 1 & 2 & 3 & 4 \\
\hline Walory smakowe potraw & 4,86 & 4,91 & 4,98 \\
\hline Walory zapachowe potraw & 4,79 & 4,43 & 4,75 \\
\hline Walory wizualne potraw & 4,68 & 4,49 & 4,83 \\
\hline $\begin{array}{l}\text { Szeroki i urozmaicony asortyment } \\
\text { potraw uwzględniający różnorodne } \\
\text { preferencje klientów }\end{array}$ & 4,57 & 4,55 & 4,92 \\
\hline Oryginalność oferty menu & 4,46 & 4,40 & 4,82 \\
\hline $\begin{array}{l}\text { Zróżnicowanie i dostosowanie oferty } \\
\text { karty menu do pór dnia }\end{array}$ & 4,46 & 4,26 & 4,83 \\
\hline $\begin{array}{l}\text { Dostosowanie oferty żywieniowej } \\
\text { do indywidualnych potrzeb klienta }\end{array}$ & 4,18 & 4,43 & 4,73 \\
\hline Gotowe zestawy oferowane w menu & 3,57 & 3,72 & 4,15 \\
\hline Przystępne ceny & 4,86 & 4,77 & 4,92 \\
\hline
\end{tabular}


Tabela 2, cd.

\begin{tabular}{|l|c|c|c|}
\hline \multicolumn{1}{|c|}{1} & 2 & 3 & 4 \\
\hline $\begin{array}{l}\text { Atrakcyjność wizualna kart menu, } \\
\text { ulotek }\end{array}$ & 3,50 & 3,66 & 3,65 \\
\hline $\begin{array}{l}\text { Duża wartość odżywcza } \\
\text { serwowanych potraw }\end{array}$ & 4,64 & 4,47 & 4,85 \\
\hline $\begin{array}{l}\text { Specjalności dań narodowych/ } \\
\text { /regionalnych oferowane w menu }\end{array}$ & 4,07 & 4,25 & 4,75 \\
\hline $\begin{array}{l}\text { Wprowadzanie produktów } \\
\text { sezonowych do menu }\end{array}$ & 4,25 & 4,47 & 4,83 \\
\hline Specjalne oferty okolicznościowe & 1,93 & 3,60 & 3,55 \\
\hline
\end{tabular}

Źródło: Badanie własne.

Na postrzeganie jakości usługi gastronomicznej przez klienta duży wpływ ma profesjonalizm i zaangażowanie personelu obsługowego. W 2013 roku uczestniczący w badaniu najwyżej ocenili zaangażowanie obsługi w realizację zamówienia. W przypadku hoteli czterogwiazdkowych doceniono także umiejętności pracowników oraz ich wygląd zewnętrzny. W opinii ankietowanych obsługa hoteli trzygwiazdkowych wykazuje się lepszą niż czterogwiazdkowych wiedzą na temat własnej oferty. Klienci hoteli o wysokim i średnim standardzie najgorzej ocenili wiedzę obsługi w zakresie aktualnych trendów w gastronomii. W lokalach hoteli dwugwiazdkowych najwyżej oceniono wygląd obsługi, a najniżej jej umiejętności. W hotelach czterogwiazdkowych i dwugwiazdkowych personel wyróżniał się cierpliwością i uczciwością, nie okazał się natomiast zbyt pomocny przy doradzaniu niezdecydowanym. Uczciwość i cierpliwość została najwyżej oceniona także w lokalach trzygwiazdkowych hoteli, a zdecydowanie najniższą ocenę, zwłaszcza w porównaniu do hoteli czterogwiazdkowych, uzyskało indywidualne podejście do klienta, czyli reagowanie na jego życzenia (tab. 3).

Część badania przeprowadzonego w 2016 roku poświęcona ocenie obsługi konsumenta dowiodła, że goście podczas kontaktu z personelem największą uwage zwracali na życzliwe nastawienie i indywidualne podejście do klienta oraz czas realizacji zamówienia. Duże znaczenie dla osób mających kontakt z kelnerem odgrywało też reagowanie na ich oczekiwania i prośby, łatwość nawiązywania kontaktu z gościem, w dalszej kolejności szybkość obsługi, czas oczekiwania na wezwaną obsługę oraz zdolność doradzania niezdecydowanym klientom. Profesjonalizm personelu i jego wiedza na temat oferowanych produktów, zaangażowanie w realizację zamówienia oraz wygląd zewnętrzny i schludność personelu także absorbowały uwagę gości, najmniejsze zaś znaczenie miała znajomość aktualnych trendów gastronomicznych. 
Tabela 3

Ocena personelu obsługowego w lokalach gastronomicznych hoteli w zależności od standardu obiektu w 2013 roku

\begin{tabular}{|l|c|c|c|}
\hline \multirow{2}{*}{ Oceniane elementy usługi } & \multicolumn{3}{|c|}{ Średnia ocena w hotelach } \\
\cline { 2 - 4 } & $\begin{array}{c}\text { dwu- } \\
\text { gwiazdkowych }\end{array}$ & $\begin{array}{c}\text { trzy- } \\
\text { gwiazdkowych }\end{array}$ & $\begin{array}{c}\text { cztero- } \\
\text { gwiazdkowych }\end{array}$ \\
\hline $\begin{array}{l}\text { Wygląd zewnętrzny, schludność } \\
\text { personelu }\end{array}$ & 3,55 & 3,72 & 4,00 \\
\hline $\begin{array}{l}\text { Zaangażowanie w realizację } \\
\text { zamówienia }\end{array}$ & 3,25 & 4,10 & 4,25 \\
\hline $\begin{array}{l}\text { Wiedza obsługi o oferowanych } \\
\text { produktach }\end{array}$ & 3,02 & 4,00 & 3,80 \\
\hline $\begin{array}{l}\text { Znajomość aktualnych trendów } \\
\text { gastronomicznych }\end{array}$ & 2,80 & 3,20 & 3,22 \\
\hline $\begin{array}{l}\text { Umiejętność pracowników } \\
\text { (roznoszenie dań, podawanie ich) }\end{array}$ & 2,27 & 3,85 & 4,15 \\
\hline $\begin{array}{l}\text { Stosunek do klienta pod względem } \\
\text { uczciwości i cierpliwości }\end{array}$ & 3,47 & 4,32 & 4,47 \\
\hline $\begin{array}{l}\text { Zdolność doradzania } \\
\text { niezdecydowanym klientom }\end{array}$ & 3,00 & 3,87 & 3,25 \\
\hline $\begin{array}{l}\text { Sposób przekazywania informacji } \\
\text { przez obsługę }\end{array}$ & 3,32 & 3,77 & 3,80 \\
\hline $\begin{array}{l}\text { Łatwość nawiazywania kontaktu } \\
\text { z klientem }\end{array}$ & 3,20 & 3,85 & 4,15 \\
\hline Indywidualne podejście do klienta & 3,17 & 3,35 & 4,05 \\
\hline
\end{tabular}

Źródło: Badanie własne.

Analizując zależność między czynnikami związanymi z obsługą konsumenta a kategorią hotelu, stwierdzono, że w hotelach dwu- i trzygwiazdkowych najbardziej istotne były odpowiednio: czas realizacji zamówienia i życzliwe nastawienie do klientów, najmniej zaś znajomość aktualnych trendów gastronomicznych. W hotelach czterogwiazdkowych największe znaczenie dla jakości oferty gastronomicznej miały: wiedza personelu o oferowanych produktach, życzliwe nastawienie do klientów, czas realizacji zamówienia, indywidualne podejście do klienta. Średnie znaczenie odgrywały: szybkość obsługi, łatwość nawiązywania kontaktu z klientem, czas oczekiwania na wezwaną obsługę, reagowanie na oczekiwania i prośby klientów oraz profesjonalny personel. Mniej istotny dla tej oceny był wygląd zewnętrzny, schludność personelu oraz zdolność doradzania niezdecydowanym klientom (tab. 4). 
Tabela 4

Wpływ czynników związanych z obsługą konsumenta na ocenę jakości oferty gastronomicznej w hotelach zależnie od kategorii w 2016 roku

\begin{tabular}{|c|c|c|c|}
\hline \multirow{2}{*}{$\begin{array}{l}\text { Czynniki związane z obsługa } \\
\text { konsumenta }\end{array}$} & \multicolumn{3}{|c|}{ Kategoria hotelu } \\
\hline & $\begin{array}{c}\text { dwu- } \\
\text { gwiazdkowych }\end{array}$ & $\begin{array}{c}\text { trzy- } \\
\text { gwiazdkowych }\end{array}$ & $\begin{array}{c}\text { cztero- } \\
\text { gwiazdkowych* }\end{array}$ \\
\hline Szybkość obsługi & 4,71 & 4,70 & 4,93 \\
\hline Profesjonalny personel & 4,64 & 4,72 & 4,90 \\
\hline $\begin{array}{l}\text { Życzliwe nastawienie do klientów/ } \\
\text { /gości }\end{array}$ & 4,75 & 4,91 & 4,95 \\
\hline $\begin{array}{l}\text { Wygląd zewnętrzny, schludność } \\
\text { personelu }\end{array}$ & 4,61 & 4,62 & 4,88 \\
\hline $\begin{array}{l}\text { Zaangażowanie w realizację } \\
\text { zamówienia }\end{array}$ & 4,71 & 4,68 & 4,90 \\
\hline Czas realizacji zamówienia & 4,86 & 4,75 & 4,95 \\
\hline $\begin{array}{l}\text { Czas oczekiwania na wezwana } \\
\text { obsługe }\end{array}$ & 4,61 & 4,77 & 4,92 \\
\hline $\begin{array}{l}\text { Wiedza personelu o oferowanych } \\
\text { produktach }\end{array}$ & 4,57 & 4,74 & 4,97 \\
\hline $\begin{array}{l}\text { Znajomość aktualnych trendów } \\
\text { gastronomicznych }\end{array}$ & 4,32 & 4,23 & 4,80 \\
\hline $\begin{array}{l}\text { Łatwość nawiązywania kontaktu } \\
\text { z klientem }\end{array}$ & 4,75 & 4,70 & 4,93 \\
\hline Indywidualne podejście do klienta & 4,68 & 4,87 & 4,95 \\
\hline $\begin{array}{l}\text { Zdolność doradzania } \\
\text { niezdecydowanym klientom }\end{array}$ & 4,64 & 4,74 & 4,87 \\
\hline $\begin{array}{l}\text { Reagowanie na oczekiwania i prośby } \\
\text { klientów }\end{array}$ & 4,71 & 4,74 & 4,92 \\
\hline
\end{tabular}

Źródło: Badanie własne.

\section{Wnioski}

Z przeprowadzonych badań wynika, że zarówno w 2013 roku, jak i w 2016, wyżej oceniane przez gości lokali gastronomicznych działających w strukturze hoteli były elementy związane z obsługą niż ofertą. W zakresie oferty dań do najwyżej ocenianych czynników należały walory organoleptyczne potraw (smak, zapach i wygląd), wielkość porcji, oferta potraw i napojów, nakrycie stołu, jak również cena dań i napojów. Klienci obiektów hotelarskich o wyższym standardzie większą uwage przywiązywali do indywidalizacji usługi. Jest to związane z rosnącymi oczekiwaniami klienta wraz ze wzrostem standardu obiektu hotelarskiego. 
Z analizy ocen czynników związanych z obsługą i personelem wynika, że w 2013 roku największe znaczenie miało zaangażowanie personelu w realizację zamówienia, stosunek do klienta (uczciwość i życzliwość), wygląd, a także komunikatywność. W 2016 roku klienci wskazywali na czas realizacji zamówienia oraz - zwłaszcza w hotelach o wyższym standardzie (od czterogwiazdkowych) - indywidualne podejście do klienta.

W obu okresach badawczych elementy związane z obsługą klienta znacznie wyżej oceniano w gastronomii hoteli o wyższej kategorii, co jest związane z koniecznością dbania o standardy i budowania przywiązania (lojalności) klienta do tych obiektów.

\section{Literatura}

CIEŚLIK E., CIEŚLIK J., WASILEWSKI P., TURCZA K., SIEMBIDA A., 2014: Ocena jakości ustug gastronomicznych jako czynnik zwiększajacy zaufanie konsumentów, Journal of Agribusiness and Rural Development 3 (33), 15-24.

CIEŚLIK E., OSTROWSKA D., BODZIOCH A., 2011: Jakość ustug gastronomicznych jako czynnik podnoszenia konkurencyjności w hotelarstwie, Turystyka i Rekreacja, 7, 105-108.

DROGOŃ W., GRANECKA-WRZOSEK B., 2013: Podstawy hotelarstwa i ustugi dodatkowe. Podręcznik do nauki zawodu technik hotelarstwa, wyd. III, WSiP, Warszawa.

GRANECKA-WRZOSEK B., 2013: Ustugi żywieniowe w hotelarstwie. Podręcznik do nauki zawodu technik hotelarstwa, WSiP, Warszawa.

KNOWLES T., 2001: Zarzqdzanie hotelarstwem i gastronomia, PWE, Warszawa.

MAŃKOWSKI T., 2008: Obsługa gości w gastronomii, [w:] A. Panasiuk, D. Szostak (red), Hotelarstwo. Ustugi - Eksploatacja - Zarzqdzanie, Wydawnictwo Naukowe PWN, Warszawa, 325-326.

MITURA E., KONIUSZEWSKA E., 2008: Hotelarstwo - organizacja i technika pracy, wyd. II, Difin, Warszawa.

MUCHA-SZAJEK E., 2001a: Gastronomia hotelarska, Poradnik Restauratora 9, 16.

MUCHA-SZAJEK E., 2001b: Obstuga gastronomiczna w obiekcie hotelowym, Poradnik Restauratora $7,44$.

NADULSKI R., 2011: Jakość uslug gastronomicznych $w$ wybranych hotelach w Lublinie, [w:] D. Kołożyn-Krajewska, Z.J. Dolatowski (red.), Jakość ustug turystycznych i żywieniowych, Wydawnictwo WSZHiT, Częstochowa, 153-161.

Rozporządzenie Ministra Sportu i Turystyki z dnia 16 listopada 2011 r. zmieniające rozporządzenie w sprawie obiektów hotelarskich i innych obiektów, w których są świadczone usługi hotelarskie, Dz.U. 2011, nr 259, poz. 1553.

SALA J., 2011: Marketing w gastronomii, wyd. II zmien., PWE, Warszawa.

ŚWIĄTKOWSKA M., 2009: Ustugi hotelarskie, [w:] H. Górska-Warsewicz, E. Świstak (red.), Funkcjonowanie przedsiębiorstwa hotelarskiego, Wydawnictwo SGGW, Warszawa, 97-98. 


\section{Abstrakt}

Celem pracy była ocena usług warszawskich hoteli w zakresie oferty usług gastronomicznych oraz czynników związanych z obsługą konsumenta. Wyniki badań wykazały wzrost poziomu świadczonych usług gastronomicznych wraz z podwyższeniem standardu obiektu. Głównym determinantem jakości tych usług, niezależnym od standardu hotelu, okazała się właściwa obsługa konsumenta. W zakresie oferty największe znaczenie miały walory organoleptyczne potraw, sposób ich podania oraz cena. Największe znaczenie w sferze czynników związanych z obsługą miały zaangażowanie personelu, jego stosunek do klienta oraz komunikatywność. Klienci lokali gastronomicznych obiektów o wyższym standardzie oczekiwali usługi bardziej zindywidualizowanej, dostosowanej do ich potrzeb.

Słowa kluczowe: hotel, oferta gastronomiczna, ocena jakości usług

\section{Gastronomic offer of Warsaw hotels in their guests opinion}

\section{Abstract}

The aim of the study was to evaluate the gastronomy services of Warsaw hotels for services offer and personnel. The results of the survey showed an increasing overall rating of catering services as the hotel standard grew. The proper determination of the catering services quality, independent of the standard of the hotel, has proved to be the right service for the consumer. The organoleptic qualities of the dishes, the way they were served, and the price were most important factors determining services offer. Employees' involvement, customer attitude and communicativeness were the most important factors determining customer service. Customers of hotels offering higher-standard gastronomy were expecting more personalized service, tailored to their needs.

Key words: hotel, gastronomic offer, service quality evaluation 
